\title{
The flatworm's turn
}

\section{Washington}

THE question of which person's genes will be mapped and sequenced by the US human genome initiative is still open, but under the genome programme of the US National Institutes of Health (NIH), the humble nematode may be the first higher organism to have its genes ordered into a physical map. At its second meeting last week, NIH's advisory committee on the human genome project unanimously agreed to endorse a joint effort by US and British researchers to finish the nematode gene map.

It has always been clear that the genome effort will not provide the sequence of one individual's genes, but rather an amalgam of human DNA from various sources. But mapping and sequencing human genes will be only a part of the genome initiative: further studies of the genomes of such well-studied 'model organisms' as the Escherichia coli bacterium, the fruit fly Drosophila, the nematode and the mouse have been discussed as stepping-stones

James Watson, who divides his time as director of both the Cold Spring Harbor Laboratory and the NIH Office of Human Genome Activities, brought up the idea of putting NIH's initial efforts into sequencing the nematode genome at the advisory committee meeting. He says researchers at the British Medical Research Council's (MRC) Laboratory of Molecular Biology at Cambridge and at Washington University Medical School in St Louis, Missouri, have broken down the genome of the nematode into 200 sets of overlapping DNA fragments, or 'contigs'.

By bridging breaks between contigs towards the human genome.

using the yeast artificial chromosome technique developed at Washington University (see Nature 335, 184; 1988), Watson believes the team can whittle the nematode genome down to 100 contigs in roughly a year. Putting the contigs in their correct order will provide a physical map of the nematode, which he believes can then be sequenced by a team of 50 technicians within six years.

Watson estimates that a three-year, $\$ 600,000$ grant would allow the US-British collaboration to finish the physical map and start sequencing. At 100 million base pairs of DNA, the nematode genome is roughly the size of an average human chromosome. The nematode's biology is so well understood - it is known to have exactly 958 cells, and each cell division during development has been completely described - Watson says "the worm people may lead the way" in genome research.

But Congress is not likely to smile on a proposal to spend part of the $\$ 100$ million the Bush administration has earmarked for the genome initiative next year on a worm, especially if part of it will go to research outside the United States. The NIH genome advisory committee, chaired by Norton Zinder of Rockefeller University, must report to Congress next spring on how the genome project should proceed. In the meantime, MRC's Michael Kemp says he has a proposal from the British group on his desk, and Washington University's Robert Waterston says his group is "doing its homework" to submit a grant application once NIH issues its request for applications for 1990 genome programme grants next month.

Carol Ezzell HUMAN GENOME

\section{Sequencing by committee}

\section{Tokyo}

WhateVer happened to the human genome project in Japan? A couple of years ago, there were fears in the United States that if a project were not started there immediately, Japan would steal the lead. But while the United States and Europe have long since established organizations to sequence the human genome, Japan's efforts have hardly got beyond the committee report stage.

Last month a subcommittee of the Science Council of Japan, a non-government body elected directly by academics, issued a report recommending a greatly expanded effort. Two subcommittees of the Ministry of Education, Science and Culture also recently submitted similar recommendations to the ministry's own science council. And last year the Science and Technology Agency (STA) issued a vaguely-worded call for a project but gave no indication of the direction it should take (Nature 334, 5; 7 July 1988).

But apart from a small-scale effort at STA's institute of physical and chemical research (RIKEN) to develop automatic DNA sequencing machines, a project started many years ago by Professor Akiyoshi Wada of Tokyo University, there is no project under way in Japan.

Kenichi Matsubara of the Institute of Molecular and Cellular Biology of Osaka University, head of one of the education ministry's subcommittees, says that, even if the ministry's science council accepts the subcommittee's recommendations when it meets to discuss them next month, it will be at least two years before government funds will be available to support a project.

Meanwhile, with the council's approval, Matsubara says the subcommittee

\section{Lyons laboratory monkeys recaptured}

Paris

TWENTY-EIGHT of the monkeys stolen in a raid on laboratories in Lyons earlier this month have been found in a private house at Toulon (see Nature 339, 407; 1989). Altogether, 38 monkeys and some marsupials, as well as dogs and cats, were removed in a raid by an animal rights group.

Five people were arrested in connection with the discovered animals and two have been retained for further questioning. The monkeys are said by a researcher at one of the laboratories concerned, Unit 97 of the institutes for health and medical research (INSERM), to be "in very good condition".

Police have so far not returned the monkeys to their owners for fear of provoking public protest. Since the raid, the French press has published several articles showing gruesome pictures of laboratory animals, including photographs taken during the Lyons raid.

Last Friday, animal rights campaigner Brigitte Bardot broadcast a powerful anti-vivisection documentary on French television, with a well-known cancer researcher (and former health minister), Leon Schwartzenberg, speaking against the use of animals for experiments. The broadcast gave no opportunity to biomedical researchers to defend their case and will not help their recent efforts to put animal experimentation into perspective (see Nature 339, 573; 1989). Peter Coles

hopes to launch a "small rocket" using emergency funds that the ministry sets aside for research on earthquakes and the like. The funds will be used to organize more committees of university researchers and to cope with demands for genome information from overseas by, for example, improving computer programming facilities.

The report from the Science Council of Japan calls for the establishment of an organization to coordinate a joint research effort by various government agencies and ministries: this is not an easy task in Japan because of inter-ministerial rivalries. Nevertheless, Matsubara hopes that by drawing together university researchers with 'emergency' funds from the Ministry of Education, an 'invisible committee' will be established during the next two years that could coordinate an inter-agency project.

Matsubara is Japan's representative of the Human Genome Organization (HUGO), established last year to coordinate worldwide efforts on the project; he has been trying to raise funds in Japan to support HUGO, so far without much success. As well as calling on private companies, he has approached organizers of Japan's Human Frontier Science Program.

David Swinbanks 